\title{
Calculation of Uniform Coefficient, Soil Moisture Distribution and Analysis of Level of Biofilms Strategy under Sub Surface Drip Irrigation
}

\author{
Jatoth Veeranna*, A.K. Mishra and Neelam Patel
}

\author{
Division of Agricultural Engineering, Indian Agricultural Research Institute, \\ New Delhi-12, India \\ *Corresponding author
}

A B S T R A C T

\begin{tabular}{|c|}
\hline Keywords \\
\hline $\begin{array}{l}\text { Root zone density, } \\
\text { Soil moisture } \\
\text { distribution, Sub } \\
\text { surface irrigation } \\
\text { and Uniform } \\
\text { distribution and } \\
\text { biofilms. }\end{array}$ \\
\hline Article Info \\
\hline $\begin{array}{l}\text { Accepted: } \\
07 \text { September } 2017 \\
\text { Available Online: } \\
10 \text { October } 2017\end{array}$ \\
\hline
\end{tabular}

\section{Introduction}

Subsurface drip irrigation is defined as application of water below the soil surface through emitters, with discharge rates generally in the same range as surface drip irrigation. SDI is defined as application of water below the soil surface through the emitters (Merriam and Keller 1978), with discharge rates generally in the same range as surface drip irrigation (Gilbert et al., 1981).
Subsurface Drip Irrigation (SDI) is similar to surface drip irrigation but the emitters located below the soil surface and thus the water is applied directly into the root zone. It has been used for the last 40 years and is suitable for most crops, particularly for high value fruit and vegetable as well as for turf and landscapes (Autovino et al., 2016). A drawback is that its irrigation uniformity can 
be severely affected by the obstruction of an emitter, although some field evaluations have shown uniformity coefficients similar to or even higher than those from drip irrigation (Merriam and Keller, 1978; Autovino et al., 2016).

The first field experiment in the United States with a subsurface drip irrigation system was established on a lemon orchard at Pomona, California in 1963 and on an orange orchard near Riverside, California in 1964. The first research and demonstration study on a private grower's trees was in an avocado orchard in San Diego, California in 1969 (Hassanli et al., 2010). About the same time trials were started using drip irrigation and plastic mulch on strawberries and tomatoes also in and around San Diego (Hills and Brenes, 2010; Chouhan et al., 2015) stated that in 1984 cotton farmers installed the first SDI equipment in Texas HP.

The drip irrigation system with lateral lines laid on soil surface is the most popular application method in India (Hermes et al., 2015). SDI offers many advantages over surface drip irrigation such as; reduced evaporation loss and precise placement and management of water, nutrient and pesticides leading to more efficient water use, greater water application uniformity, enhanced plant growth, crop yield and quality (Ives, 1980; Hassanli et al., 2010). The other advantages of SDI include less interference with cultural operations and improved cultural practices; allows field operations even during irrigation; less nutrient and chemical leaching and deep percolation; reduced weed germination and their growth; reduced pest and diseases; damage due to drier and less humid crop canopies; warmer soils; reduced exposure of irrigation equipment to damage; no soil crusting due to irrigation; well suited to widely spaced crops; and advantages of freedom from necessity of anchoring laterals at the beginning and removing (Bernadette and Ontermaa, 1994) it at the end of the season, and thus longer economic life, high application efficiency of $80-90 \%$ (Adin and Sacks, 1991; Hermes et al., 2015). The National Water Policy of India stresses that water is a prime natural resource, a basic human need and a precious natural asset. It is vital for realizing full potential of agricultural sector in order to get food self-sufficiency and security (Robles et al., 2016). The demand for water is increasing both in agriculture and in particular in municipal sector at significant rates (Bush et al., 2016). Indian agriculture in future has to produce ever-increasing quantities of food, fiber and fuel for increasing population of the country with decreasing quantities of water available for irrigation (Chouhan et al., 2015). Therefore, optimum and efficient utilization of water in agriculture for irrigation assumes great significance. Several methods of irrigation from traditional surface flooding to modern drip irrigation systems have been evolved (Jha et al., 2016). The traditional surface irrigation methods pose numerous problems of soil, water and environmental degradation (Aiello et al., 2007). These methods are supply driven rather than crop demand driven, which cause mismatch between the need of crop and the quantity supplied. A large part of irrigated agriculture employee surface application methods, which results in low water application efficiency.

The use of wastewater in agriculture minimizes a potential contamination source for ground and surface water, especially in arid regions where the shortage of water implies the use of every available water source. Emitter clogging, a phenomenon commonly seen in reclaimed wastewater drip irrigation systems (Ravina et al., 1992; Hassanli et al., 2010), is a severe obstacle to the wide applications and popularization of the irrigation technology. Their sensibility depends on their characteristics (Ravina et al., 
1977) and on the water quality characterized by its physical, biological and chemical properties (Nakayama et al., 2007). The constituents of reclaimed wastewaters are suspended particles, salinity ions, nitrogen, phosphorus, and organisms and microbial community clog emitters (Puig et al., 2005). The nutrients, organic substances, and trace elements contained in the reclaimed water after secondary or even tertiary treatment could sustain the growth of microorganisms. Microorganisms including various bacteria, fungi, protozoa, with large quantities, multiple types, and fast growth rates in natural water play an important role in the ecosystem. In fact, over $90 \%$ of microbes adhere to the substrate surface and exist in the form of biofilms (Li et al., 2015; Bush et al., 2016). Biofilm is a 3D heterogeneous and functional aggregation containing microbial community (bacteria, protozoa and fungi, etc.), solid particulates, extracellular polymers (EPS) secreted by microorganisms and other substances (Yang et al., 2000).Microorganisms and nutrients can pass through the filter and enter the drip irrigation system and then form biofilms following the "attachment growth-detachment-decay", process (Li et al., 2015; Nakayama 2007).

The emitters are among the most important parts of drip irrigation systems, but the narrow labyrinth path is easily clogged by pollutants, such as, suspended particulates, chemical precipitates, organic matter (OM), and microorganisms. Emitter clogging has become the major problem limiting more widespread use of drip irrigation, because it can reduce the service life and benefits of a drip irrigation system (Torabi et al., 2013). In the present research the level and characteristic of biofilms formed in the drip laterals were studied.

The evaluate how different irrigation depths applied with SDI affected the distribution of soil moisture pattern, placement of laterals to get maximum yield and water use efficiency for onion and potato crops (Jha et al., 2016; Patel and Rajput 2007). The maximum yield is recorded at 10 to $15 \mathrm{~cm}$ depth in sandy loamy soil as compared with other depths. To see the response of subsurface drip irrigation on potato yield, a study was conducted at Water Technology Centre filed (Abbott, 1985; Kandelous and Simunek, 2010). Potato crop was cultivated in three sub-plots with four treatments of drip lateral depths viz. on the surface, and at depths of $5,10,15 \mathrm{~cm}$ below the soil surface (Duran et al., 2009). Crop was irrigated as per irrigation schedule to fulfil its water requirement. The observations were recorded on growth parameter, soil moisture content and yield of crop (Nakayama et al., 2007).

\section{Materials and Methods}

\section{Experimental site}

In order to achieve the objectives set for the present study, experiments were carried out in the laboratory as well as in the field of Precision Farming Development Centre (PFDC), Water Technology Centre (WTC), ICAR-Indian Agricultural Research institute (IARI), New Delhi. (Latitude 28 37'30" $28^{\circ} 30^{\prime} 0 "$ " N, Longitude $77^{\circ} 8^{\prime} 45^{\prime \prime}-77^{\circ} 10^{\prime} 24^{\prime \prime}$ E and AMSL $228.61 \mathrm{~m}$ ) during October to February two years (2013-14, 2014-15).

\section{Soil analyses and data collection}

Soil samples were taken from different locations of the field to determine the physical and chemical properties. Experimental soil was sandy loam soil. Soil samples were collected from different depths up to $60 \mathrm{~cm}$ using tube auger and were analysed to determine its physical properties such as particle size distribution, bulk density, field capacity, permanent wilting point, soil moisture, soil matric potential and hydraulic conductivity. Methodologies adopted for 
analysis of different soil parameters are listed in Table 1. Soil samples from surface down to $30.0 \mathrm{~cm}$ at $15.0 \mathrm{~cm}$ interval were collected. Hydrometer method was followed to determine the sand, silt and clay percentage of soil. The soil of the experimental area was deep, well-drained sandy loam soil comprising $67.5 \%$ sand, $12.5 \%$ silt and $20 \%$ sandy loam for depth 0 to $15 \mathrm{~cm}$ and other details were presented in Table 1. The soil is sandy loam with mean basic infiltration rate as $8.14 \times 10-6 \mathrm{~ms}^{-1}$. Average bulk density and saturated hydraulic conductivity of soil were found to be $1.53 \mathrm{Mg} \mathrm{m}^{-3}$ and $3.08 \times 10-6 \mathrm{~ms}^{-1}$, respectively.

\section{System installation and experimental treatments}

A field plot of size $25.0 \mathrm{~m} \times 50.0 \mathrm{~m}$ was selected for experimental studies. The field plot was divided into three equal plots of 9.0 $\mathrm{m} \times 50.0 \mathrm{~m}$. Plot of $9.0 \mathrm{~m} \times 50.0 \mathrm{~m}$ size was divided into 15 equal plots of $0.60 \mathrm{~m} \times 50.0$ $\mathrm{m}$, representing a single treatment $(\mathrm{Li}$ et al., 2015). The experiment was laid out following the randomized block design (RBD) with 15 treatments and 3 replications (R1, R2 and R3) of each treatment with drip laters were installed at different depth, were presented in Table 2. Installation of the SDI system commenced in September, 2002 according to the standard guidelines. The layout of SDI system is shown in figure $1(a-d)$.

Tubers of $30 \mathrm{~g}$ weight of potato were sown at the depth of $15.0 \mathrm{~cm}$ in the raised ridges prepared during the first week of October at a plant to plant and ridge to ridge spacing of $30.0 \mathrm{~cm} \times 60.0 \mathrm{~cm}$. The base and height of ridges were kept $60.0 \mathrm{~cm}$ and $30.0 \mathrm{~cm}$, respectively. Drip tape of 12.0 mil was buried manually at depths of $0.0,5.0,10.0,15.0$ and $20.0 \mathrm{~cm}$ in the middle of ridges formed for sowing of potato under different treatment. Three different irrigation levels of 60,80 and $100 \%$ of the crop evapotranspiration and five depth of placement of drip tape were maintained in the crop. The SDI system installed had drippers spaced at $30.0 \mathrm{~cm}$, each with an application rate of $0.72 \mathrm{lph}$. One drip tape was installed for each row of potato. Time Domain Reflectometry was used in this study for determination of soil water content. Three access tubes, one at the mid of ridge and two at 15.0 and $30.0 \mathrm{~cm}$ away from the middle of ridge were installed. Access tubes were placed at the middle of the row up to a depth of $45.0 \mathrm{~cm}$ and water content (volumetric) were measured in all treatments. The total 135 access tubes made of PVC were installed in the experimental field.

\section{Estimation of uniformity of SDI system}

The uniformity of water application of the SDI system was carried out for two year. For each testing, 54 drippers were selected from head, middle and tail ends of drip tape, randomly. Collecting the outflow in cans placed below the dripper for a known duration, uniformity of water application was determined. The uniformity of water application was calculated from the statistical distribution of dripper flow rates (Payero et al., 2008) in terms of coefficient of variation (CV), distribution uniformity (DU) and statistical uniformity (SU).

The statistical coefficients CV, DU and SU were determined by using the equations 1,2 and 3 and the data were presented Table 3.

$$
\begin{aligned}
& C V=\left(\frac{s}{q}\right) \\
& D U=\left(\frac{q_{l q}}{q}\right) \times 100 \\
& S U=\left(1-\frac{s}{q}\right) \times 100
\end{aligned}
$$


Where,

$\mathrm{s}=$ Standard deviation of drippers discharge, lph

$\mathrm{q}_{\mathrm{qq}}=$ Mean of lowest one- fourth of drippers discharge, lph

$\mathrm{q}=$ Mean dripper flow rate, $\mathrm{lph}$

$\mathrm{n}=$ Number of drippers taken for observations

Five micro irrigation uniformity classifications, ranging from excellent to unacceptable, recognized by the American Society of Agricultural Engineers were used to evaluate the SDI system (Pramanik et al., 2014).

\section{Discharge ratio variation}

The Discharge ratio variations (Dra) of drip irrigation emitter were calculated by equation 4.

Dra $=\frac{\sum_{i=1}^{\mathrm{n}} \mathrm{qi}}{\mathrm{N} \overline{\mathrm{q}} \text { new }} \times 100$

Where, $q_{i}$ indicated the outflow rates of drip emitter number. $i$ tested $(1 / \mathrm{h}),{ }^{\bar{q}}$ new indicated the rated outflow rates of emitters offered by manufacturer $(1 / h)$, and $\mathrm{N}$ was the total number of experimental emitters in each treatment.

\section{Coefficient of uniformity}

The coefficient of uniformity (CU) of drip irrigation emitters was calculated by equation 5.

$\mathrm{Cu}=\left(1-\frac{\sum_{\mathrm{i}=1}^{\mathrm{n}}|\mathrm{qi}-\overline{\mathrm{q}}|}{\mathrm{N} \overline{\mathrm{q}}}\right) \times 100$

Where, $\mathrm{q}_{\mathrm{i}}$ indicated the outflow rates of drip emitter number. $\mathrm{i}$ tested $(\mathrm{l} / \mathrm{h}), \overline{\mathrm{q}}$ was the average emitter outflow of emitters tested in each treatment $(1 / h)$, and $\mathrm{N}$ was the total number of experimental emitters in each treatment.

\section{Root zone and wetting pattern under sub} surface drip irrigation system

The major design parameters controlling shape and position of the wetting zone beneath a SDI system are application rate, dripper depth, dripper spacing and irrigation application time (Fig. 4). Normally, SDI system is placed at the shallowest depth possible, consistent with avoiding damage from operations such as cultivation. The wetting patron of potato crop, root zone distribution and lateral depths showed in figure 2 and 3 . However, if the lowest available dripper rate is greater than the soil intake rate, water surfacing can often result from irrigation. This can be reduced by burying the SDI system deeper in the soil (Mailhol et al., 2011; Pramanik et al., 2014; Patel and Rajput, 2008). The shallowest effective depth of placement can be found by keeping the drip tape at varying depths. Drip tapes were placed at five depths of 0.0, 5.0, $10.0,15.0$ and $20 \mathrm{~cm}$ below the soil surface. The depth at which potato yield was found maximum was taken as the correct depth for placement of drip tape. The drip emitter was calibrated based on standard procedure (Patel and Rajput, 2008).

\section{Estimation of water requirement and irrigation application}

The weather data were collected from an automatic weather station located at $30 \mathrm{~m}$ away from the experimental field, WTC, ICAR-IARI. Reference crop evapotranspiration $\left(\mathrm{ET}_{0}\right)$ was calculated on a daily basis by using Penman-Monteith's semi empirical formula (Robles et al., 2016). Potato is a 130 days duration crop and may be divided in to four stages namely initial of 25 
days, developmental of 30 days, middle of 45 days and tuber maturity of 30 days. The actual evapotranspiration was estimated by multiplying reference evapotranspiration with crop coefficient $\left(\mathrm{ET}=\mathrm{ET}_{0} \times \mathrm{K}_{\mathrm{C}}\right)$ for different months based on crop growth stages. The crop coefficient during the crop season 2013 $14,2014-15$, was adopted as $0.50,0.65,1.15$ and 0.75 at initial, developmental, middle and tuber maturity stages, respectively (Payero et al., 2008; Torabi et al., 2013). During the initial and developmental growth stages, until tuber formation, it is essential, that soil should be kept constantly and uniformly wet to a depth of at least 10.0-15.0 cm. The water productivity was presented in Table 3 was calculated for different years by using SSD Irrigation.

\section{Potato yield and water productivity}

Manual digging of matured potato was done on February 15. Yield of potato of each treatment was recorded. The water productivity under different treatment $T_{1}, T_{2}$ and $T_{3}$ was presented in the Table 4. Statistical analysis was done by using standard analysis of variance (ANOVA). Two-probability levels 0.01 and 0.05 were considered for determination of significance.

\section{Level of biofilms and its characters}

According to standard methods for water and wastewater monitoring and analysis edited by National Environmental Protection Agency (2002), the water quality parameters of the two types of reclaimed wastewaters were shown in Table 5 and the measured parameters (including $\mathrm{TN}, \mathrm{TP}$, and $\mathrm{pH}, \mathrm{Ca}_{2}^{+}$ and $\left.\mathrm{Mg}^{+}\right)$in reclaimed water treated by FBR method and BAF method (Puig et al., 2005). The wastewaters reclaimed biological aerated filter (BAF) process were chosen as the experiment objects and then the effects of the average growth and topography of biofilms attached to the irrigation laterals and quantitative relationship between biofilms components were studied (Ravina et al., 1992; Tripati et al., 2014).

The biofilms attached on emitters revealed a gradual increasing trend with the increased running time of reclaimed water drip irrigation system. Dra and $\mathrm{CU}$ revealed a linear decrease in the early stage and a faster reduction in the $2^{\text {nd }}$ year, which was closely correlated with biofilm growth.

\section{Results and Discussions}

\section{Uniformity of SDI system}

The operating pressure of system was kept 1.0 $\mathrm{kg} \mathrm{cm}^{-2}$ during all the three crop seasons. The coefficients of variation of flow rates were found $0.045,0.042$ and 0.058 during 2013-14, 2014-15 respectively. The lesser values of CV indicated good performance of the system. CV estimated (Tripathi et al., 2014) for the in line labyrinth type drippers was reported to be 0.077 and $\mathrm{CV}$ values from 0.045 to 0.058 considered for good performance of system. The values of SU and DU were found more than $92 \%$ during all the three cropping seasons. SU and DU are more than $91 \%$ and $88 \%$ of the SDI system; the system was functioning excellent.

\section{Soil water distribution}

Water distribution in the soil around a buried dripper mainly depends on soil texture, dripper discharge and root water uptake (Wang et al., 2014).Soil samples were collected from the six points selected randomly from the experimental field at a depth of 0.0-15.0 cm, 15.0-30.0 cm and 30.0$45.0 \mathrm{~cm}$. Statistical test (Friedman's test) was revealed that the sand was significantly different at different depths $(\mathrm{P}<0.01,0.05)$ but sand, silt and clay content are not 
significantly different at different locations of the experimental field $(\mathrm{P}<0.01,0.05)$. Soil moisture distributions at different growth stages of potato at different depths of placement of drip tape are shown in figure 5.

Wetting of the soil surface started appearing in case of surface placement of drip tape and also in case of depth of placement of $5.0 \mathrm{~cm}$. When dip tapes were buried at depths of 10.0, 15.0 and $20.0 \mathrm{~cm}$ soil depth, the soil surface remained relatively dry. Soil surface appeared moist but did not get saturated when depth of placement of drip tape was more than $5.0 \mathrm{~cm}$ at all growth stages of potato. In the treatments T1, 2 and T3, soil moisture at the soil surface was found 16.5, 17.2, 14.9, 14.4, $15.5,15.9,14.5,14.0,12.0,13.0,12.9$ and $12.3 \%$, at initial, developmental, middle and maturity stage of crop, respectively (Patel and Rajput, 2007).

When drip tape was placed at the surface, more than $18.0 \%$ moisture was found at the soil depth of $15.0 \mathrm{~cm}$. But at $30.0 \mathrm{~cm}$ soil depth soil moisture was found about $12.0 \%$. When drip tape was buried at a depth of 5.0 $\mathrm{cm}$, then moisture at the surface was vary from 20.5 to $22.5 \%$ at different growth stage of crop. Upward movement of water takes place and surface soil become moist and adequate amount of moisture was found at the surface and at the $15.0 \mathrm{~cm}$ soil depth (av. 21.5 $\%)$ at different stages of potato. In treatment
T3, when drip tape was placed at depth of $10.0 \mathrm{~cm}$, it was found that the water movement due to capillary forces was not sufficient and soil moisture at the surface decreases significantly (av. 15.5\%) in comparison to treatment $\mathrm{T} 1$ and $\mathrm{T} 2$. It was observed that more than $16.0 \%$ moisture was found available in the ridge at all points in treatments T1, T2 and T3. Wetted soil bulb of $20.0 \mathrm{~cm}$ in width and $25.0 \mathrm{~cm}$ depth was having more than $18.0 \%$ moisture was observed in treatments $\mathrm{T} 1, \mathrm{~T} 2$ and $\mathrm{T} 3$. This is very conducive for good tuber formation resulting in higher yields in treatments $\mathrm{T} 1, \mathrm{~T} 2$ and $\mathrm{T} 3$.

It was observed that irrigation water should be applied in short duration and in the soils immediate vicinity of the drippers to prevent the surfacing. Roots of a plant, uses the water adjacent to them and plant needs to wait for the soil to replenish the water and plant uptakes the water from different zone. To increase the production and to achieve the higher yield, maintaining relatively high water content where replenishment of drying soil easily occurs can create conditions conducive to good plant growth therefore shallow placement of drip tape was recommended. The high water content of the soil around the drippers maintains relatively high soil hydraulic conductivity and good replenishment of water taken up by roots.

Table.1 Soil physical properties of different layers

\begin{tabular}{|c|c|c|c|c|c|c|c|}
\hline \multirow{2}{*}{$\begin{array}{c}\text { Soil layer } \\
\text { depth } \\
(\mathbf{c m})\end{array}$} & \multicolumn{3}{|c|}{$\begin{array}{c}\text { Particle size } \\
\text { distribution }(\%)\end{array}$} & \multirow{2}{*}{$\begin{array}{c}\text { Soil texture } \\
\text { class }\end{array}$} & $\begin{array}{c}\text { FC* } \\
\text { BD* } \\
(\mathbf{g} / \mathbf{c c})\end{array}$ & $\begin{array}{c}\text { on } \\
\text { gravimetric } \\
\text { basis } \\
(\%)\end{array}$ & $\begin{array}{c}\text { PWP* } \\
(\%)\end{array}$ \\
\cline { 2 - 4 } & Sand & Silt & Clay & & & 30.5 & 9.8 \\
\hline $0-15$ & 67.5 & 12.5 & 20 & Sandy loam & 1.32 & 30.1 & 9.3 \\
\hline $15-30$ & 66.1 & 13.1 & 20.8 & Sandy loam & 1.38 & 29.8 & 12.8 \\
\hline $30-45$ & 65.9 & 12.8 & 21.3 & Sandy loam & 1.47 & 2.4 & 16.8 \\
\hline $45-60$ & 64.9 & 13.3 & 21.8 & Sandy loam & 1.48 & 30.1 & \\
\hline
\end{tabular}

$* \mathrm{BD}=$ Bulk density, $\mathrm{FC}=$ Field Capacity, $\mathrm{PWP}=$ Permanent Wilting Point 
Table.2 Depth of placement of drip lateral

\begin{tabular}{|l|c|c|c|c|c|c|}
\hline \multirow{2}{*}{$\begin{array}{c}\text { Water balance } \\
\text { components }(\boldsymbol{\%})\end{array}$} & \multicolumn{6}{|c|}{ Depth of placement of drip lateral, $\mathbf{~ m}$} \\
\cline { 2 - 7 } & $\mathbf{0 ~ c m}$ & $\mathbf{5} \mathbf{~ c m}$ & $\mathbf{1 0} \mathbf{~ c m}$ & $\mathbf{1 5} \mathbf{~ c m}$ & $\mathbf{2 0} \mathbf{~ m m}$ & $\mathbf{3 0} \mathbf{~ c m}$ \\
\hline Soil evaporation & 12.3 & 13.1 & 10.8 & 7.5 & 4.5 & 4.2 \\
\hline Root water uptake & 85.7 & 85.8 & 88.5 & 90.2 & 91.3 & 78.1 \\
\hline Drainage & 8.3 & 5.2 & 4.2 & 3.2 & 8.9 & 12.5 \\
\hline Total & 100 & 100 & 100 & 100 & 100 & 100 \\
\hline Root zone storage & -5.4 & -5.2 & -1.6 & -3.8 & -5.8 & -5.1 \\
\hline
\end{tabular}

Table.3 Uniformity coefficient, distribution uniformity and application efficiency

\begin{tabular}{|c|c|c|c|c|c|c|}
\hline \multirow{2}{*}{ Lateral position, cm } & \multicolumn{2}{|c|}{ Uniformity Coefficient (\%) } & \multicolumn{2}{|c|}{ Distribution uniformity \% } & \multicolumn{2}{|c|}{ Application efficiency \% } \\
\cline { 2 - 7 } & Smooth & Spiral & Smooth & Spiral & Smooth & Spiral \\
\hline $\mathbf{0}$ & 80.1 & 89.0 & 71.8 & 89.5 & 86.2 & 90.4 \\
\hline $\mathbf{5}$ & 82.5 & 85.9 & 71.3 & 76.9 & 83.4 & 91.4 \\
\hline $\mathbf{1 0}$ & 85.2 & 88.3 & 81.2 & 80.5 & 79.8 & 88.3 \\
\hline $\mathbf{1 5}$ & 80.7 & 86.5 & 74.9 & 84.0 & 88.4 & 89.3 \\
\hline
\end{tabular}

Table.4 Water productivity of potato crop under sub surface drip irrigation system

\begin{tabular}{|c|c|c|c|c|c|c|}
\hline \multirow{2}{*}{ Lateral depth, cm } & \multicolumn{6}{|c|}{ Water productivity in different years } \\
\cline { 2 - 7 } & \multicolumn{3}{|c|}{ T1 } & \multicolumn{2}{|c|}{ T2 } & \multicolumn{2}{c|}{ T3 } \\
\cline { 2 - 7 } & 2013 & 2014 & 2013 & 2014 & 2013 & 2014 \\
\hline 0 & 40.8 & 47.8 & 41.8 & 51.5 & 44.1 & 51.7 \\
\hline 5 & 42.8 & 49.0 & 43.6 & 50.2 & 40.1 & 54.9 \\
\hline 10 & 40.4 & 52.6 & 46.9 & 55.0 & 48.7 & 58.0 \\
\hline 15 & 40.8 & 51.7 & 44.1 & 53.0 & 47.8 & 55.7 \\
\hline
\end{tabular}

Table.5 Average water quality characteristics of reclaimed water used during the experiment

\begin{tabular}{|c|c|c|c|c|c|}
\hline Parameter & BAF & FBR & Parameters & BAF & FBR \\
\hline $\mathrm{COD}$ & 48 & 32 & $\mathrm{P}^{\mathrm{H}}$ & 7.20 & 7.21 \\
\hline $\mathrm{SS}$ & 12.5 & 24 & $\mathrm{TSS}$ & 23 & 75 \\
\hline $\mathrm{NH}_{3}-\mathrm{N}$ & 0.33 & 0.7 & $\mathrm{CA}^{2+}$ & 68.7 & 65.8 \\
\hline $\mathrm{NO}_{2}-\mathrm{N}$ & 0.2 & 1 & $\mathrm{Mg}^{2+}$ & 10.9 & 7.1 \\
\hline $\mathrm{NO}_{3}-\mathrm{N}$ & 0.5 & 2 & $\mathrm{Fe}^{3+}$ & 0.15 & 0.41 \\
\hline $\mathrm{TN}$ & 7.0 & 7.4 & $\mathrm{Mn}$ & 0.05 & 0.11 \\
\hline $\mathrm{TP}$ & 1.7 & 2.8 & $\mathrm{DO}$ & 3.7 & 1.3 \\
\hline
\end{tabular}

COD: Chemical Oxygen Demand; SS: Suspended Solid; TN: Total Nitrogen; TP: Total Phosphorus; DO: Dissolved Oxygen 
Fig.1 Installation of sub surface drip irrigation (main and sub mine lines and laterals) in the field

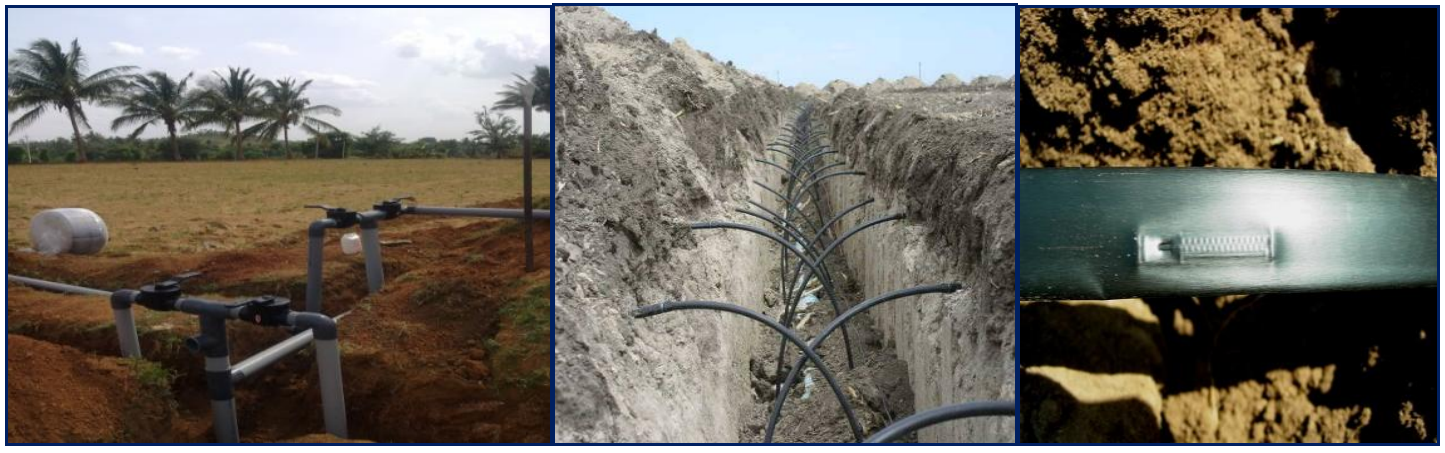

(a)

(b)

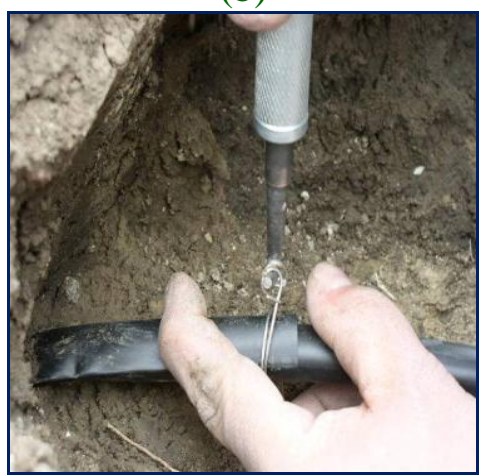

(d)

(c)

Fig.2 Root zone distribution under sub surface drip irrigation methods

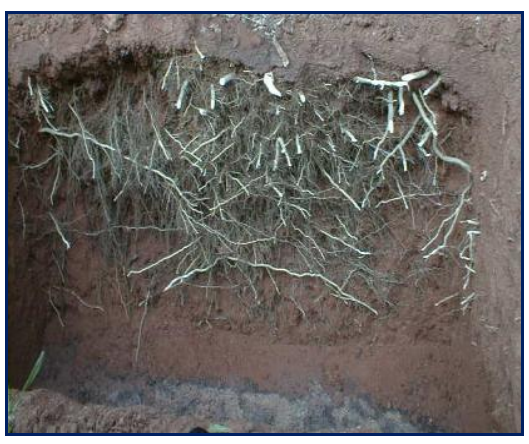

Fig.3 Wetting pattern distribution under sub surface drip irrigation methods

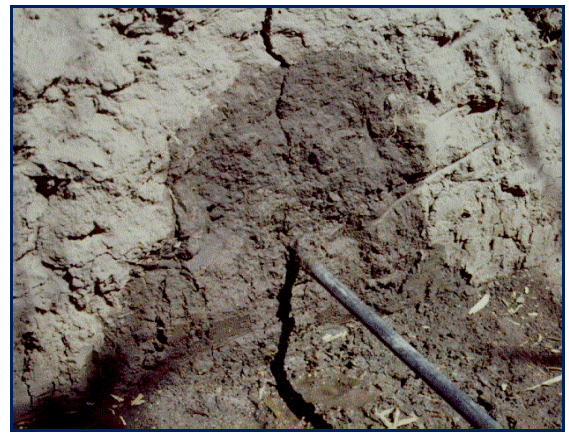


Fig.4 Average observed potato yield under sub surface drip irrigation system for 2013-14 and 2014-15

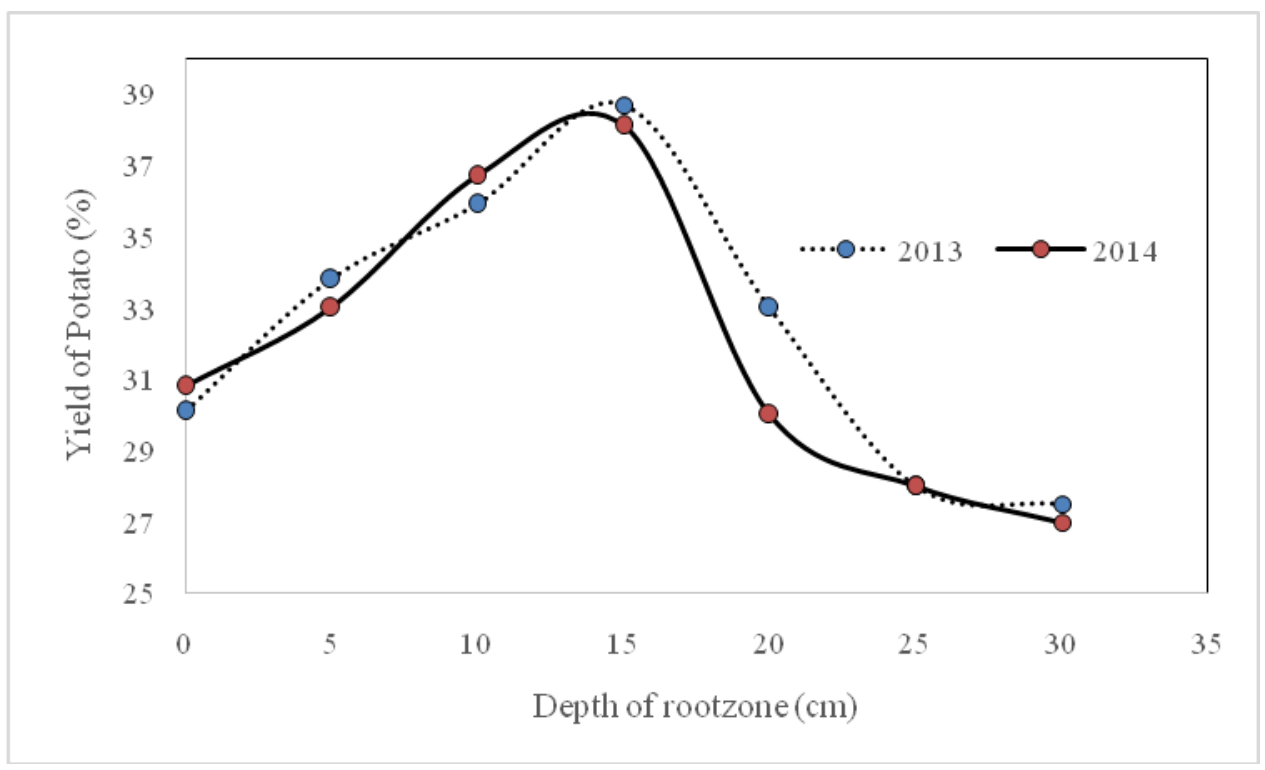

Fig.5 Partially accumulation of the biofilm inside and outside the laterals and online emitters

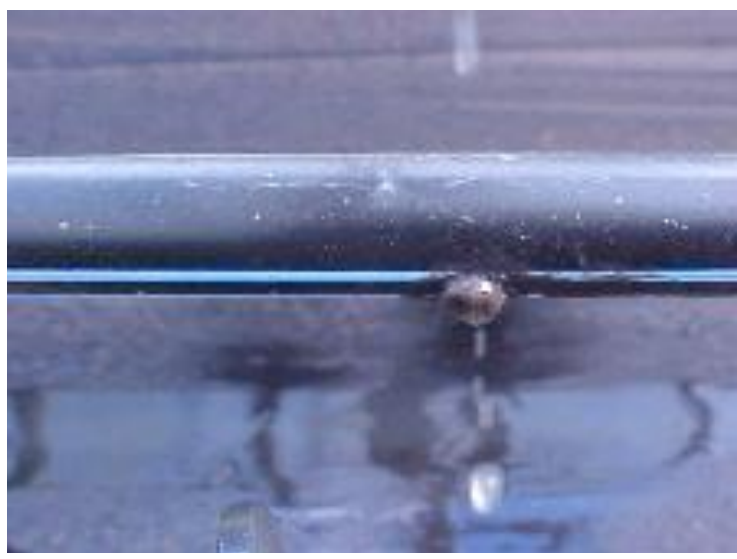

Fig.6 Full accumulation of the biofilm inside and outside the laterals and online emitters
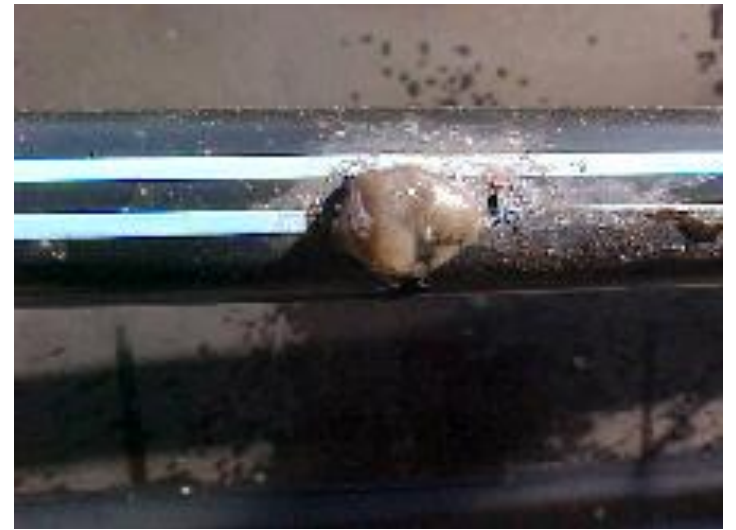
Fig.7 Increased level of biofilm inside and outside the laterals and online emitters for a different durations

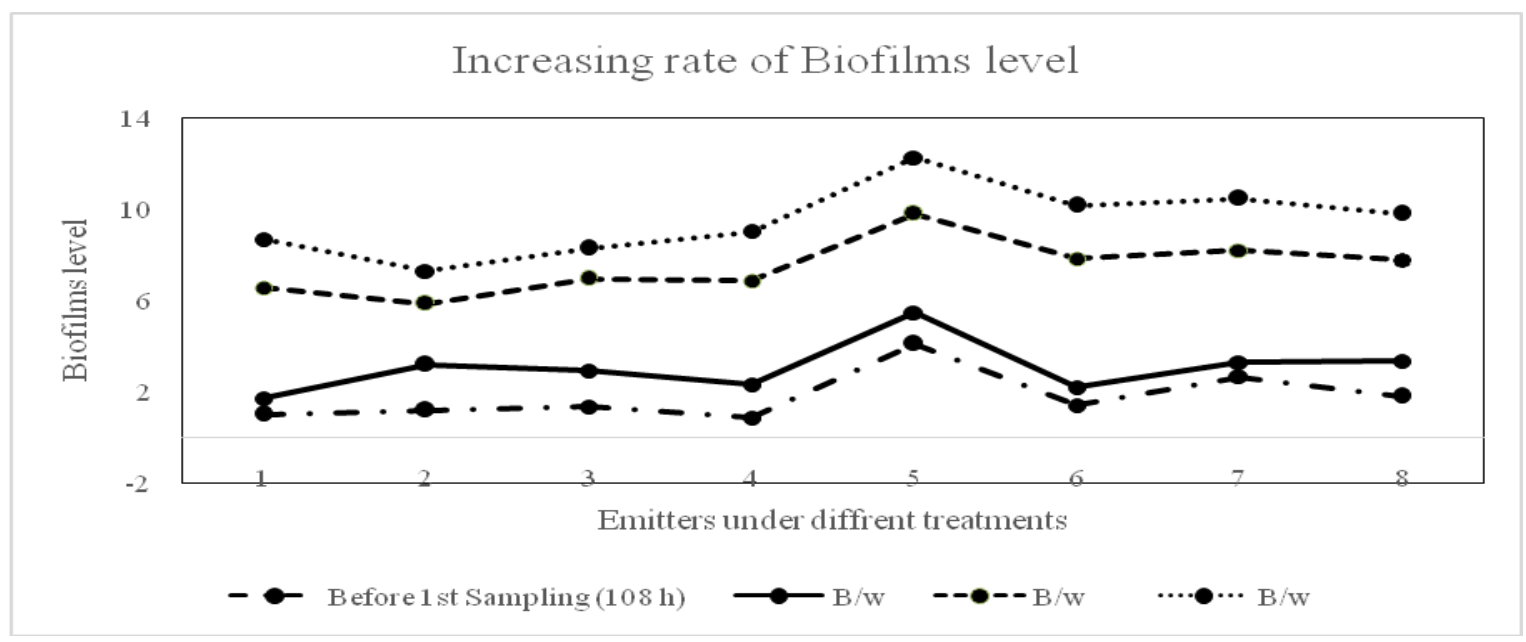

Fig.8 SEM images of suspended particulates in BAF reclaimed wastewater

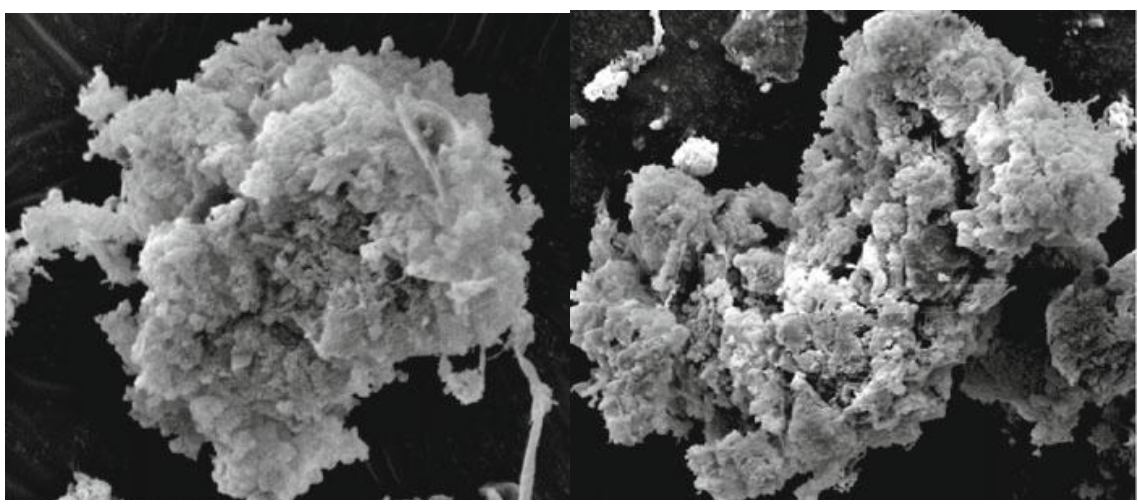

Effect of depth of placement of drip tape on potato yield

Maximum yield of potato was recorded during the year 2013-14 and 2014-15. The highest yield was recorded in treatment $\mathrm{T} 3$ (37.3 $\left.\mathrm{tha}^{-1}\right)$ and lowest in case of 0.6T1 (18.5 $\mathrm{t} \mathrm{ha}^{-1}$ ) as shown in Figure 3. Potato yield was higher under SDI than surface drip irrigation system during two years of experimentation. Potato yield was significantly affected by the placement of drip tape and maximum yield was obtained by placing the drip tape at 10.0 $\mathrm{cm}$ soil depth $(\mathrm{P}<0.05)$. It was observed that the drip tape could be buried either at 10.0 or $15.0 \mathrm{~cm}$ depth without significantly affecting the yield (CD at $5 \%$ are $0.6,0.55$ and 0.66$)$. It was recommended that to achieve the higher yields, drip tape should be buried at $10.0 \mathrm{~cm}$ depth. Levels of irrigation and depth of placement of drip tape significantly affected the mean yield of tuber in all three years $(\mathrm{P}<0.05)$.

\section{Relationship with emitter clogging}

As shown in Table 5, biofilm showed an increasing trend as the increase in running time of drip irrigation system (Figure 4). The average rate biofilms attached on pressure compensating and non-pressure compensating emitters were $18.4884 \mu \mathrm{g}$ and $19.55 \mu \mathrm{g}$ after 
$204 \mathrm{~h}$, and they reached $63.81 \mu \mathrm{g}$ and 90.48 $\mu \mathrm{g}$ after $540 \mathrm{~h}$, respectively. On the other hand, the increasing rates of attached biofilm showed the fast-slow-fast-slow trend during different periods, which were $0.14,0.02,0.30$, and $0.11 \mu \mathrm{g} / \mathrm{h}$, respectively.

During the initial fast-growth stage the biofilms thickness increased linearly and the biofilms accumulated. Increased level of biofilm inside and outside the laterals and online emitters for different durations was presented in Figure 5. During the later period the biofilms grew slowly and its thickness fluctuated because there was a dynamic procedure of growth, detachment, and regrowth (Fig. 7). There was a unimodal type of relationship between velocity and thickness of biofilms attached to two reclaimed wastewater laterals during the fast growth period and the SEM images of suspended particulates in BAF reclaimed wastewater image were presented in figure 6. Yan et al., (2009) concluded that a close relationship with the processes of attachment growth, and detachment decay of biofilms in drip irrigation system (Fig. 8).

The coefficient of variation of flow rates was found $0.045,0.042$ and 0.058 during 2013-14, 2014-15 respectively. The lower values of CV indicated good performance of the SDI system. The values of SU and DU were found more than $92.0 \%$ during all the three cropping seasons. Soil moisture distribution at different growth stages of potato at different depths of placement of drip tape was monitored. When drip tape was buried at $5.0 \mathrm{~cm}$ soil depth, upward movement of water takes place and surface soil become moist and at the $15.0 \mathrm{~cm}$ soil depth about $21.5 \%$ moisture was found at different growth stages of potato. Drip tape buried at the depth of $10.0 \mathrm{~cm}$, it was found that the water movement due to capillary forces is not sufficient particularly in sandy loam soil and soil moisture at the surface decreases. When drip tapes were buried at the depths of 15.0 and $20.0 \mathrm{~cm}$, the soil surface remains relatively dry and moisture increases at the $30.0 \mathrm{~cm}$ soil depth at all growth stages of crop and water moves beyond the ridge base. In potato, the tubers formation was confined within the ridges, therefore water moves beyond the ridge base was not available for plants at any stage of growth.

Potato yield was higher under SDI than surface drip irrigation system during all years of experimentation. Highest yield was recorded in treatment $\mathrm{T} 3\left(33.3 \mathrm{t} \mathrm{ha}^{-1}\right)$ and lowest in case of $0.6 \mathrm{~T} 1\left(18.5 \mathrm{t} \mathrm{ha}^{-1}\right)$. Higher yield potential can be achieved at $10 \mathrm{~cm}$ and $15 \mathrm{~cm}$ depth of placement laterals for Onion and Potato respectively. Cost of Subsurface drip irrigation is more as compared to other irrigation system. The growth and detachment of biofilms were the main reason of the clogging of drip irrigation system. The biofilms attached on emitters showed an increasing trend with the increased running time of reclaimed water drip irrigation system, while the increasing rates represented the fast-slow; fast-slow trend in different periods as head, middle and tail end.

\section{Acknowledgments}

This work was supported by the Precision Farming Development Centre (PFDC), WTC, ICAR-IARI, New Delhi. My thanks extend to Er. Sundarm, Scientist Agricultural Engineering for giving his inputs and suggestion about this work.

\section{References}

Abbott, J.S., 1985. Emitter clogging causes and prevention. ICID Bull. 34 (2), 1120.

Adin, A., and Sacks, M., 1991. Dripperclogging factors in wastewater irrigation. J. Irrig. Drain. Eng. 117 (6), 813-826. 
Aiello, R., Cirelli, G. L., and Consoli, S. 2007. Effects of reclaimed wastewater irrigation on soil and tomato fruits: a case study in Sicily (Italy). Agricultural Water Management, 93(1), 65-72.

Autovino, D., Provenzano, G., Monserrat, J., Cots, L., and Barragán, J. (2016). Determining Optimal Seasonal Irrigation Depth Based on Field Irrigation Uniformity and Economic Evaluations: Application for Onion Crop. Journal of Irrigation and Drainage Engineering, 04016037

Bernadette, and Ontermaa, E., 1994. Citrus micro sprinkler clogging: Analysis of clogging in drip emitters during wastewater irrigation. Appl. Eng. Agric. 22 (2), 251-257.

Bush, A., Elamin, A. M., Ali, A. B., and Hong, L. 2016. Effect of different operating pressures on the hydraulic performance of drip irrigation system in Khartoum State conditions. Journal of Environmental and Agricultural Sciences, 6, 64-68.

Capra, A., and Scicolone, B. 2007. Recycling of poor quality urban wastewater by drip irrigation systems. Journal of Cleaner Production, 15(16), 1529-1534.

Chouhan, S. S., Awasthi, M. K., and Nema, R. K. 2015. Studies on water productivity and yields responses of wheat based on drip irrigation systems in clay loam soil. Indian Journal of Science and Technology, 8(7), 650.

Duran-Ros, J. Puig-Bargues., and Arbat G. 2009. Effect of filter, emitter and location on clogging when using effluents. Agricultural water management, 96(1), 67-79.

Gilbert, R., G., Nakayama, F, S., Bucks, D, A., and Adamson, K, C., 1981. Trikle irrigation: emitter clogging and flow problems. Agricultural Water Management, 3:159-178.
Hassanli, A. M., Ahmadirad, S., and Beecham, S. 2010. Evaluation of the influence of irrigation methods and water quality on sugar beet yield and water use efficiency. Agricultural Water Management, 97(2), 357-362.

Hermes, E., Boas, M. A. V., Rodrigues, L. N., De Melo, E. L., and Berger, J. S. 2015. Process capacity index in drip irrigation with cassava wastewater processing. African Journal of Agricultural Research, 10(12), 1427-1433.

Hills, D.J., and Brenes, M.J., 2001. Microirrigation of wastewater effluent using drip tape. Appl. Eng. Agric. 17 (3), 303-308.

Ives, K.J., 1980. Deep bed filtration: theory and practice. Filtr Sep. 17 (2), 157-166.

Jha, A. K., Malla, R., Sharma, M., Panthi, J., Lakhankar, T., Krakauer, N. Y., and Shrestha, M. L. 2016. Impact of Irrigation Method on Water Use Efficiency and Productivity of Fodder Crops in Nepal. Climate, 4(1), 4.

Kandelous, M. M., and Simunek, J. 2010. Numerical simulations of water movement in a subsurface drip irrigation system under field and laboratory conditions using HYDRUS2D. Agricultural Water Management, 97(7), 1070-1076.

Li, Y., Song, P., Pei, Y., and Feng, J. (015. Effects of lateral flushing on emitter clogging and biofilm components in drip irrigation systems with reclaimed water. Irrigation Science, 33(3), 235245.

Mailhol, J. C., Ruelle, P., Walser, S., Schütze, N., and Dejean, C. 2011. Analysis of AET and yield predictions under surface and buried drip irrigation systems using the Crop Model PILOTE and Hydrus-2D. Agricultural Water Management, 98(6), 1033-1044.

Merriam, J.L., and Keller, J., 1978. Farm Irrigation Evaluation: A Guide for 
Management. Department of Agricultural and Irrigation Engineering, Utah State University, Logan, Utah. Ravina.1-275(3).

Nakayama, F.S., Boman, B.J., and Pitts, D.J., 2007. Micro irrigation for Crop Production. Design, Operation, and Management. Elsevier, Amsterdam, 389-430.

Patel, N., and Rajput, T. B. S. (2007). Effect of drip tape placement depth and irrigation level on yield of potato. Agricultural water management, 88(1), 209-223.

Payero, J. O., Tarkalson, D. D., Irmak, S., Davison, D., and Petersen, J. L. 2008. Effect of irrigation amounts applied with subsurface drip irrigation on corn evapotranspiration, yield, water use efficiency, and dry matter production in a semiarid climate. Agricultural water management, 95(8), 895-908.

Pramanik, S., Ray, R., and Patra, S. K. 2014. Effect of drip vis-à-vis surface irrigation on fruit yield, water use and distribution efficiency of banana in Gangetic plain of West Bengal. Indian Journal of Horticulture, 71(2), 176-183.

Puig Bargues, J., Barragan, J., Ramırez de Cartagena, F., 2005. Filtration of effluents for microirrigation systems. Trans. ASAE 48 (3), 969-978.

Ravina, I., Paz, E., Sofer, Z., Marcu, A., Shisha, A., Sagi, G., 1992. Control of emitter clogging in drip irrigation with reclaimed wastewater. Irrigation Sci. 13 (3), 129-139.
Ravina, I., Paz, E., Sofer, Z., Marcu, A., Shisha, A., Sagi, G., Yechialy, Z., and Lev, Y., 1997. Control of clogging in drip irrigation with stored treated municipal sewage effluent. Agric. Water Manage. 33 (2), 127-137.

Robles, J. M., Botía, P., and Pérez-Pérez, J. G. 2016. Subsurface drip irrigation affects trunk diameter fluctuations in lemon trees, in comparison with surface drip irrigation. Agricultural Water Management, 165, 11-21.

Torabi, M., Midmore, D. J., Walsh, K. B., Bhattarai, S. P., and Tait, L. 2013. Analysis of factors affecting the availability of air bubbles to subsurface drip irrigation emitters during oxygation. Irrigation Science, 31(4), 621-630.

Tripathi, V. K., Rajput, T. B. S., and Patel, N. 2014. Performance of different filter combinations with surface and subsurface drip irrigation systems for utilizing municipal wastewater. Irrigation Science, 32(5), 379-391.

Wang, Z., Li, J., and Li, Y. 2014. Effects of drip irrigation system uniformity and nitrogen applied on deep percolation and nitrate leaching during growing seasons of spring maize in semi-humid region. Irrigation Science, 32(3), 221236.

Yang, X, M., Beyenal, H., Harkin, G., and Lewandowski Z, 2000. Quantifying biofilm structure using image analysis. Journal of Microbiological Methods, 39(2): 109-119.

\section{How to cite this article:}

Jatoth Veeranna, A.K. Mishra and Neelam Patel. 2017. Calculation of Uniform Coefficient, Soil Moisture Distribution and Analysis of Level of Biofilms Strategy under Sub Surface Drip Irrigation. Int.J.Curr.Microbiol.App.Sci. 6(10): 713-726. doi: https://doi.org/10.20546/ijcmas.2017.610.088 